\title{
ПЕДАГОГІЧНІ УМОВИ ФОРМУВАННЯ ІНФОРМАЦІЙНО- АНАЛІТИЧНОЇ КОМПЕТЕНТНОСТІ В КУРСАНТІВ ВІЙСЬКОВОГО ІНСТИТУТУ У ПРОЦЕСІ ФАХОВОЇ ПІДГОТОВКИ
}

\author{
SERHII MARCHENKOV, head of the department military institute \\ S.P. Korolo 's post-graduate student of the chair of pedagogy \\ Zhytomyr Ivan Franko State University, Ukraine
}

\section{PEDAGOGICAL CONDITIONS OF FORMATION OF INFORMATION- ANALYTICAL COMPETENCE IN MILITARY INSTITUTE WHILE PROFESSIONAL TRAINING}

\begin{abstract}
У статті показано необхідність формування інформаційно-аналітичних компетентностей у курсантів військового інституту, проаналізовано педагогічні умови формування інформаційно-аналітичної компетентності у процесі їх фахової підготовки. Проведено теоретичний аналіз педагогічних умов, які б відповідали сучасним вимогам та інформаційно-аналітичній компетентності майбутніх офіцерів.

Ключові слова: педагогічні умови, майбутній офіцер, професійна підготовка, інформаційно-аналітичні вміння, інформаційно-аналітична діяльність, інформаційно-аналітична компетентність, процес фахової підготовки.
\end{abstract}

Summary. The article reveals the need for the formation of information and analytical competenc among cadets of a military institute. During training, future officers receive the basic skills that help is them become professionals in their field, as well as develop themselves as individuals. Therefore, now the question is urgently in accordance with the pedagogical conditions of modern requirements and the use of information and analytical communication tools in the educational process. The article is devoted to the analysis of the pedagogical conditions for the formation of information and analytical competence among cadets of a military institute while professional training. A

(C) С. Марченков theoretical analysis of the pedagogical conditions that meet modern requirements and information and analytical competence of future officers has been under sturdy.

Key words: pedagogical conditions, future officer, professional training, information and analytical skills, information and analytical activity, information and analytical competence, the process of professional training.

Мета: проаналізувати та обгрунтувати педагогічні умови відповідно до сучасних вимог для інформаційноаналітичної компетентності майбутніх офіцерів у процесі фахової підготовки.

Постановка проблеми в загальному вигляді. Сучасний процес освіти перебуває у стані постійних змін, які відбуваються з метою якісної та максимально швидкої підготовки сучасних фахівців, які станугь конкурентоспроможними та зможуть повноцінно реалізувати свій потенціал. Збільшення впливу інформаційних концепцій суспільного розвитку, стрімке зростання обсягу і ролі інформації, розширення освітніх можливостей в умовах інформованого навчання висувають нові вимоги до особистості та компетентнісних характеристик курсантів військового інституту, що, у свою чергу, передбачають оптимізацію змісту їх фахової підготовки у вищих військових навчальних закладах.

Широке використання сучасних педагогічних та інформаційно-аналі- тичних комунікаційних засобів в освітньому процесі робить можливим підвищення навчально-пізнавальної активності майбутніх офіцерів; забезпечення якості навчання на рівні вимог сучасного інформаційного суспільства; створення умов для інтелектуального розвитку курсантів, розкриття їхнього творчого потенціалу; підвищення рівня фахової підготовки майбутніх офіцерів та їх конкурентоспроможності на міжнародному ринку інтелектуальної праці; підвищення рівня інформаційно-аналітичної культури та підготовки.

Аналіз теоретико-методологічних основ показує, що формувальний характер освітнього процесу вищого військового навчального закладу досягається шляхом створення певних педагогічних умов. Виявлення та забезпечення цих умов необхідні для успішного вирішення завдань щодо формування інформаційно-аналітичної компетентності майбутнього офіцера. Тільки з урахуванням відповідних педагогічних умов загальна структура процесу навчання та фахова підготовка майбутніх офіцерів набудуть конкретного змісту.

Аналіз досліджень і публікацій. До детального аналізу питань, що стосуються розкриття педагогічних умов формування інформаційно-аналітичної компетентності в курсантів військового інституту у навчальному процесі, приділяють дослідники А. Алексюк, А. Аюрзанайн, О. Гермак, Г. Голубова, А. Зубко, В. Семиченка, 
В. Манько Б. Чижевський, К. Ярощук та інші.

Так, на думку В. Семиченка, педагогічні умови - це сукупність об'єктивних можливостей змісту навчання, методів, організаційних форм та матеріальних можливостей здійснення підготовки, що забезпечують успішне вирішення поставленого завдання (Семиченко, 2004).

В. Манько педагогічні умови визначає як взаємопов'язану сукупність внугрішніх параметрів та зовнішніх характеристик функціонування, яка забезпечує високу результативність навчального процесу і відповідає психолого-педагогічним критеріям оптимальності (Манько, 2000).

На основі сказаного вище сформулюємо власне визначення. Отже, ми під педагогічними умовами формування інформаційно-аналітичної компетентності курсантів розуміємо необхідні й достатні обставини, за яких освітній процес забезпечує ефективний розвиток інформаційно-аналітичної компетентності майбутніх офіцерів у процесі їх фахової підготовки.

Для визначення педагогічних умов у нашому дослідженні ми ставимо певні завдання. Перше з них - забезпечення процесу ефективного формування інформаційно-аналітичної компетентності курсантів військових інститутів у процесі навчання фахових дисциплін - полягає у тому, щоб допомогти їм на основі інформаційно-аналітичних методів отримати необхідні знання, сформувати власні поняття та уявлення про свою професійну компетентність, її зміст і функції. Друге завдання стосується надання допомоги в організації власної інформаційно-аналітичної діяльності, тобто їх взаємодії з іншими людьми, 3 професійними завданнями на службі.

Розуміння цього дозволило нам обгрунтувати педагогічні умови, що необхідні для успішного вирішення зазначеної проблеми, та розкрити їхній зміст. Для визначення впливу окреслених умов формування інформаційно-аналітичної компетентності майбутнього офіцера ЗС України у процесі фахової підготовки нами було проведено опитування викладачів Львівського, Київського, Хмельницького та Житомирського вищих військових навчальних закладів. Респондентам пропонувалось виділити 3 двадцяти наведених умов п'ять, які на їхню думку, є найбільш значущими у процесі формування інформаційно-аналітичної компетентності майбутніх офіцерів.

Наші дослідження засвідчили, що в освітньому процесі вищих військових навчальних закладів під час фахової підготовки позитивні результати супроводжуються такими педагогічними умовами формування інформаційно-аналітичної компетентності майбутніх офіцерів:

- належне мотиваційне забезпечення освітнього процесу щодо формування інформаційно-аналітичної компетентності у процесі фахової підготовки;

- упровадження інтегрованого та особистісно зорієнтованого підходів до формування інформаційно-аналітичної компетентності курсантів у процесі навчання фахових дисциплін;

- залучення курсантів військових інститутів 3С України до спеціально організованої, розвивальної, навчально-пізнавальної, рефлексивної діяльності, спрямованої на одержання, зберігання, обробку та передачу інформації.

• діалогічний, інтегрований характер процесу формування інформаційно-аналітичної компетентності майбутніх офіцерів ЗС України у процесі фахової підготовки;

- творчий рівень інформаційноаналітичної активності майбутніх офіцерів при вивченні фахових дисциплін.

Виклад основного матеріалу дослідження. Над проблемою мотиваційного забезпечення освітнього процесу щодо формування інформаційно-аналітичної компетентності майбутнього офіцера у процесі фахової підготовки працювали вчені Н. Баловсяк, О. Зайцева, В. Ільїна, О. Ярошенко та ін., котрі визначають мотив як внутрішній стимул особистості, спонукання її до виконання певної дії.

У своєму дослідженні ми виходимо 3 того, що мотивація навчальної діяльності - це система мотивів, які спонукають людину оволодівати знаннями та способами пізнання, свідомо ставитись до навчання, проявляти пізнавальнуактивність.

Важливим завданням сучасної освіти є мотивація курсантів на необхідність оволодіння елементами інформаційноаналітичної компетентності, тобто "вміння самостійно шукати, аналізувати й відбирати необхідну інформацію, організовувати, перетворювати, зберігати й передавати іï, володіння інформаційними технологіями, прийомами застосування комп'ютерної техніки тощо" (Краевский, 2007).
Таким чином, важливо спрямовувати курсантів на необхідність оволодіння інформаційно-аналітичною компетентністю, тобто вміти користуватися інформаційними технологіями, аналізувати, синтезувати, критично відбирати, опрацьовувати, зберігати і передавати інформацію.

Інтеграція, як зазначають В. Краєвський та А. Хуторськой, проявляється в об'єднанні різних інформаційних компетентностей у процесі навчання, а саме: навичок діяльності з визначення певної інформації в освітніх галузях, умінь користуватися сучасними засобами інформації (телевізор, айфон, смартфон, факс, ноутбук, принтер, модем, ксерокс і т. д.) та інформаційними технологіями (аудіо- відеозаписи, електронна пошта, 3МI, Інтернет), пошук, аналіз та збір необхідної інформації, їі перевірка, збереження та передама (Беспалко, 2002).

Отже, інтегрований підхід у фаховій підготовці для формування інформаційно-аналітичної компетентності у військовому інституті є провідним. Визнання курсанта головною фігурою всього освітнього процесу служить основою для застосування особистісно зорієнтованої педагогіки.

Для того, щоб майбутній офіцер став інформаційно та аналітично компетентним, протягом усього періоду навчання необхідно враховувати його індивідуальні особливості, навички, прагнення до використання нових інформаційних технологій у фаховій підготовці та майбугній діяльності. Для цього можна виділити наступні шляхи: удосконалення навчального плану і навчальних програм; розгляд процесу навчання з позиції інтеграції; масове впровадження на лекційних, практичних і лабораторних заняттях нових технічних засобів навчання; викладання спецкурсів 3 питань формування інформаційно-аналітичної компетентності курсантів військових інститугів.

Особистісно зорієнтований підхід ми розглядаємо не як просте пристосування до наявного рівня знань, умінь, навичок і психічного розвитку кожного окремо взятого курсанта, а як таку адаптивну модель навчання, яка дозволила б кожномузасвоїти навчальну програму у власному ритмі. Це повинно привести до такого оволодіння змісту базових дисциплін, яке відповідало можливостям кожного й забезпечувало б максимальне, ефективне засвоєння матеріалу.

Проаналізуємо третю педагогічну умову - залучення курсанта військо- 
вого інституту до спеціально організованої, розвивальної, навчальнопізнавальної, рефлексивної діяльності, спрямованої на формування його інформаційно-аналітичної компетентності.

Проблему комплексного використання інформаційних засобів ми вирішуємо як з технічної, так і методичної сторони. Адже, наприклад, відсутність принтера чи іншого периферійного обладнання, збій у програмі можуть кардинально змінити методи вирішення певного дидактичного завдання. Не менш важливою $\epsilon$ організаційно-плановий чинник, тобто йдеться про чітке визначення моментів початку і завершення використання того чи іншого засобу з навчально-методичного комплексу, паралельне їх застосування у процесі вирішення дидактичних завдань.

У свою чергу, перехід до ефективної реалізації загальнодоступної освіти та особистісно орієнтованого навчання стає можливим не тільки внаслідок того, що модифікуються організаційні форми навчання, але і через те, що з'явились і з'являються такі засоби навчання, які засновані на використанні інформаційно-комп'ютерних технологій.

Четвертою педагогічною умовою нашого дослідження виступає діалогічний характер процесу формування інформаційно-аналітичної компетентності в майбутніх офіцерів при вивченні базових дисциплін. Діалог виступає основою творчого мислення, особливою формою суб'єкт-суб'єктивної взаємодії. Навчальний діалог $\epsilon$ не тільки формою навчання для досягнення цілей педагогічного процесу, а й допомагає його учасникам співпрацювати, пізнати один одного, самовияву, діяти в умовах навчальної ситуації. Його конструктивний характер також сприяє формуванню інформаційно-аналітичної компетентності майбутніх офіцерів.

Забезпеченню діалогічного характеру навчання у військовому інституті допомагають застосування групової роботи 3 курсантами, проведення різноманітних дискусій, диспугів, круглих столів, виконання проєктних завдань, розв'язання проблемних ситуацій, проведення "мозкових атак" тощо. Таким чином, усе це створюватиме умови для розвитку в майбутніх офіцерів критичного, аналітичного мислення, мовлення, встановлення контакту з іншими людьми, розкриття особистості студента. Водночас відбу- ватиметься своєрідний діалог з особистістю через дидактичні вимоги.

П'ятою педагогічною умовою формування інформаційно-аналітичної компетентності майбутнього офіцера ЗС України у процесі вивчення фахової підготовки є творчий рівень активності особистості курсанта військового інститугу. Саме активність особистості визначає ступінь включення курсанта в навчальну діяльність, що й обумовлює ступінь сформованості інформаційно-аналітичних умінь загалом. Проте мова не йде про примус до творчої активності, а про створення відповідних умов для iii прояву, що іє одним із завдань педагога у процесі викладання фахових дисциплін у військовому інституті. Цьому сприяє створення належної психолого-педагогічної атмосфери на заняттях, використання різних форм та методів організації навчальної діяльності, професійно спрямованих ситуацій, стимулювання до інформаційноаналітичної діяльності, аналіз курсантами результатів власної інформаційно-аналітичної діяльності, заохочення ïx знаходити й використовувати власні способи роботи з інформацією, обирати найбільш раціональні з них тощо.

Засобами реалізації педагогічних умов формування інформаційно-аналітичної компетентності курсантів у процесі фахової підготовки є застосування комп'ютерних програм, мультимедійних технологій, інтернет-технологій, визначення та побудова бази даних, використання засобів телекомунікації, робота з електронними бібліотеками, кредитно-модульні технології, електронні посібники тощо.

Саме перелічене нами, дозволяє розглядати ефективність інформаційно-аналітичної діяльності майбутніх фахівців військової справи.

Висновки та перспективи подальших досліджень. Отже, формування інформаційно-аналітичної компетентності майбутнього офіцера ЗС України при вивченні фахових дисциплін у вищому військовому навчальному закладі є однією із складових професійної компетентності військовослужбовця.

\section{СПИСОК ЛІТЕРАТУРИ}

Ашеров, А., Логвіненко, В. (2005). Методи і моделі оцінки педагогічного впливу на розвиток пізнавальної самостійності студентів. Харьков : УІПА.

Березюк, О., Власенко, О. (2017). Дидактика: теорія і практика. Жито- мир : Вид-во ЖДУ ім. І. Франка.

Беспалко, В. (2002). Образование и обучение с участием ИТО (педагогика третьего тысячелетия). Воронеж :МОДЕК.

Выготский, Л. (1991). Педагогическая психология. Москва : Педагогика.

Краевский, В. (2007). Основы обучения. Дидактика и методика. Москва : Издательский центр "Академия".

Манько, В. (2000). Дидактичні умови формування у студентів професійно-пізнавального інтересу до спеціальних дисциплін. Соиіалізачія особистості, 2, 153-161.

Новак, М. (1999). Современные технологии в образовании. Новые знания, 3, 17-21.

Петренко, Л. (2013). Теорія і практика розвитку інформаційно-аналітичної компетентності керівників професійно-технічних навчальних закладів. Дніпропетровськ : IMA-прес.

Семиченко, В. (2004). Психологія педагогічної діяльності. Київ : Вища школа.

\section{REFERENCES}

Asherov, A., Logvinenko, V. (2005). Methods and models of pedagogical assessment influence on the development of cognitive independence of students. Kharkov: UIPA.

Berezyuk, O., Vlasenko, O. (2017). Didactics: theory and practice. Zhytomyr : Vid-vo ZhDU Im. I. Franka.

Bespalko, V. (2002). Education and training with the participation of ITO (pedagogy of the third millennium). Voronezh: MODEK.

Vygotsky, L. (1991). Pedagogical Psychology. Moscow : Pedagogy.

Kraevsky, V. (2007). Fundamentals of training. Didactics and methodology. Moscow : Akademiya Publishing Center.

Manko, V. (2000). Didactic conditions of formation of students of professional and cognitive interest in special disciplines. Socialization of personality. Kyiv: Logos.

Novak, M. (1999). Modern technologies in education. New knowledge, 3, 17-21.

Petrenko, L. (2013). Theory and practice of development of information and analytical competence of heads of vocational schools. Dnepropetrovsk : IMA Press.

Semichenko, V. (2004). Psychology of pedagogical activity. Kyiv : Higher School.

Стаття надійшла 3.02.2020 p. 